\title{
PENERAPAN ACTIVITY BASED COSTING SYSTEM SEBAGAI DASAR PENETAPAN TARIF JASA RAWAT INAP PADA RUMAH SAKIT ROEMANI MUHAMMADIYAH SEMARANG
}

\author{
Oleh: \\ Mohammad Afifudin \\ R. Ery Wibowo Agung S \\ Jurusan Akuntansi \\ Fakultas Ekonomi \\ Universitas Muhammadiyah Semarang \\ Email: Superpipo90@gmail.com
}

\begin{abstract}
The purpose of this study was to gain knowledge about the determination of rates of hospitalization services using activity based costing, can be used as reference in setting tariffs inpatient services at Rumah Sakit Roemani Muhammadiyah Semarang and as means comparison with the rates of hospitalization for this set, as well as being one of that input provide information about activity based costing, especially in its application to a hospital that is the main orientation of community service.

The method of analysis used descriptive method is to use the comparative analysis of the current hospital rates, set the cost method is based on activity based costing, and then compare the hospitalization rates based on activity based costing with its realization.

The results showed that the calculation of hospitalization rates by using activity based costing, when compared with the rates used by the hospital activity based costing provides greater results for Class, IIB, PICU, dan BBRT and yields smallaer for class UTAMA, IA, IB,II, IIA, III dan R.BAYI. This is because the overhead loading on each product. On activity based costing, overhead costs for each product are charged to costs a lot of drivers. So that the activity based costing, has
\end{abstract}


been able to allocate the cost of the activity room kesetiap appropriately based on the consumsion of aech activity.

Keywords: activity based costing and cost driver.

\section{PENDAHULUAN}

\section{Latar Belakang}

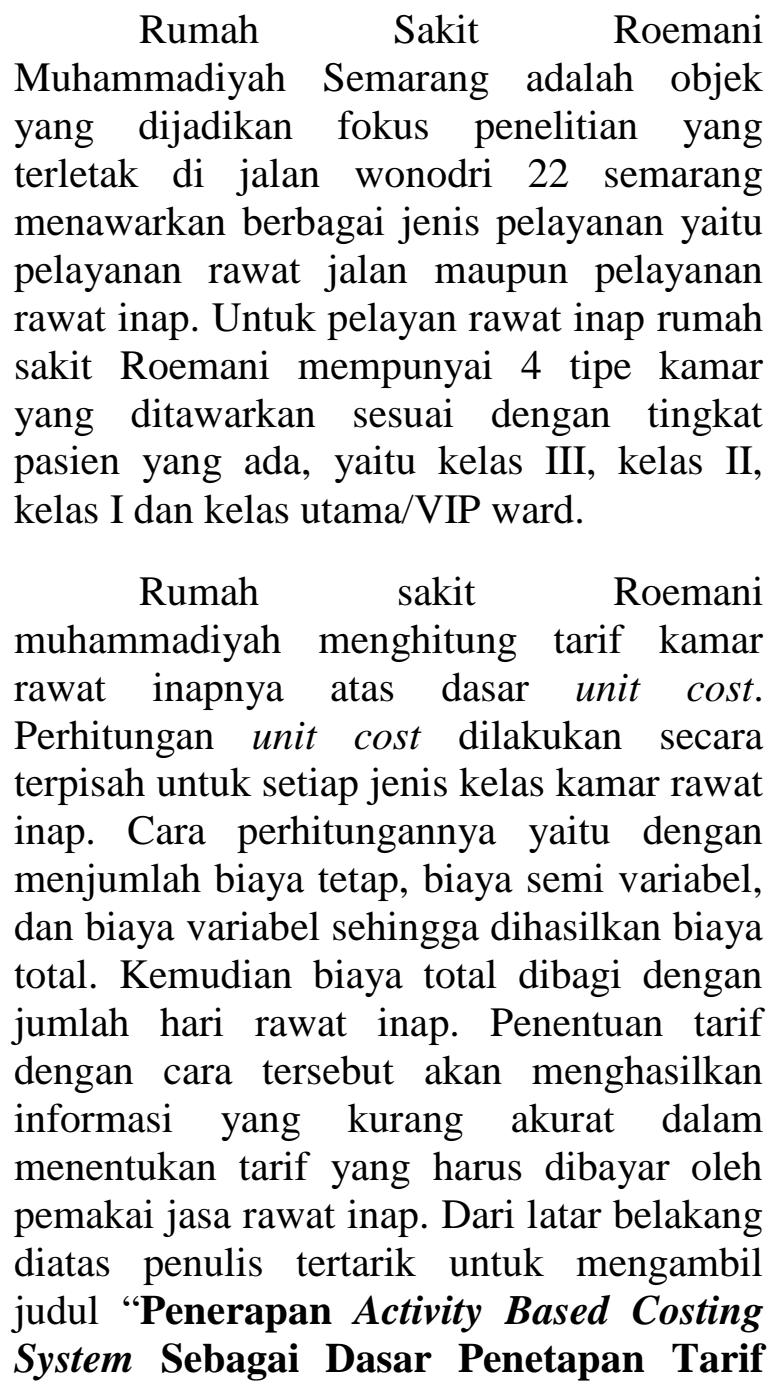

Jasa Rawat Inap Pada Rumah Sakit Roemani."

\section{Tujuan Penelitian}

Tujuan Penelitian ini adalah untuk mengetahui kemungkinan penerapan Activity Based Costing di Rumah Sakit Roemani dan hubungannya dengan biaya dan aktivitas yang efesien.

\section{LANDASAN TEORI}

\section{Pengertian Biaya}

Biaya adalah kas atau nilai ekuivalen yang dikorbankan untuk mendapatkan barang atau jasa yang diharapkan memberikan manfaat saat ini atau dimasa dating bagi organisasi (Hansen dan Mowen 2006).

\section{Klasifikasi Biaya \\ Hansen dan Mowen (2006 ) mengklasifikasikan biaya menurut prilakunya. Dalam menilai prilaku biaya, pertama yang harus dipertimbangkan adalah batasan waktu, dalam jangka panjang semua biaya dalah variable. Sedangkan dalam jangka pendek, paling tidak satu biaya adalah biaya tetap. Kemudian harus diidentifikasi sumber-sumber daya yang dibutuhkan dan output aktivitas.}

\section{System Akuntansi Biaya Tradisional}


Perhitungan produk dalam system biaya tradisional menggunakan penggerak aktivitas tingkat unit (Unit Activity Cost Drivers). "Penggerak aktivitas tingkat unit adalah faktor yang menyebabkan perubahan dalam biaya seiring dengan perubahan jumlah unit yang diproduksi (Hansen dan Mowen , 2006).

\section{Activity Based Costing}

Menurut Garrison dan Norren (2000) "Activity Based Costing adalah metode costing yang dirancang untuk menyediakan informasi biaya bagi manajer untuk pembuatan keputusan stratejik dan keputusan lain yang mempengaruhi kapasitas dan biaya tetap". Pengambil keputusan yang berpengalaman tidak menggunakan informasi akuntansi tanpa mempertimbangkan potensi ketidakakuratannya. Data yang tidak akurat dapat menyesatkan dan menghasilkan kesalahan yang berpotensi menghasilkan keputusan yang kurang optimal. Dengan adanya Activity Based Costing dapat dihitung harga pokok satu produk atau jasa yang dapat digunakan oleh manajemen sebagai salah satu alternatif untuk penentuan harga jual.

\section{Activity Based Costing Pada Perusahaan Jasa}

System kerja activity based costing
banyak diterapkan pada perusahaan manufaktur, tetapi juga dapat diterapkan pada perusahaan jasa. Penerapan metode activity based costing pada perusahaan jasa memilki beberapa ketentuan khusus, hal ini disebabkan oleh karakteristik yang disebabkan oleh karakteristik yang dimilki perusahaan jasa.

\section{METODE PENELITIAN}

\section{Desain Penelitian}

Penelitian ini menggunakan metode deskriptif dengan pendekatan studi kasus. Studi kasus dengan memakai pendakatan deskriptif yaitu dengan menggambarkan pemecahan masalah dalam suatu kasus dengan dengan menggunakan metode Activity Based Costing.

\section{Metode Pengumpulan Data}

1. Wawancara dilakukan langsung dengan pihak yang berkepentingan dalam memberi penjelasan dalam penentuan harga pokok jasa.

2. Dokumentasi yaitu metode ini digunakan untuk memperoleh data mulai dari catatan-catatan atau dokumen-dokumen yang ada atau tersedia di RS Roemani yang berhubungan dengan penelitian ini.

3. Studi Kepustakaan ini dilakukan dengan literature-literatur dan sumber-sumber lain untuk mendapatkan landasan teori yang cukup untuk mendukung analisa penelitian.

4. Studi Lapangan dimaksudkan untuk pencarian data dengan jalan terjun langsung ke objek penelitian untuk memperoleh data yang asli guna diolah lebih lanjut.

\section{Teknik Analisis}

a. Mengklasifikasikan aktivitas pengkonsumsian sumber daya.

b. Penelusuran cost ke aktivitas jasa sehingga berhubungan dengan cost obyek supaya dapat dipertanggungjawabkan.

c. Penghitungan penentuan harga pokok jasa. 


\section{HASIL DAN PEMBAHASAN}

\section{Gambaran Umum Perusahaan}

Rumah Sakit Roemani didirikan pada hari rabu pon tanggal 27 agustus 1975 M (19 sya'ban 1395 H) dengan maksud sebagai sarana da'wah untuk mengamalkan amar ma'ruf nahi munkar, mewujudkan Persyarikatan Muhammadiyah. Nama Roemani digunakan sebagai penghargaan atas kepeloporan dan pemrakarsa berdirinya sebuah pelayanan kesehatan. Beliau, $\mathrm{H}$. Achmad Roemani, mewakafkan bangunan di atas tanah seluas 13.000 meter persegi milik Persyarikatan Muhammadiyah yang terletak di jalan Wonodri 22 Semarang.

Berikut adalah visi dan misi yang diterapkan pada rumah sakit muhammadiyah roemani semarang beserta motto:

Visi

Visi Rumah Sakit Roemani Muhammadiyah Semarang yaitu " Menjadi Rumah Sakit terkemuka dalam pelayanan prima yang dijiwai nilai-nilai islam dan didukung aplikasi teknologi mutakhir.

Misi

Misi dari Rumah Sakit Roemani Muhammadiyah Semarang yaitu:

1. Rumah Sakit Roemani sebagai media dakwah amar ma'ruf nahi munkar untuk mewujudkan cita-cita persyarikatan muhammadiyah.

2. Rumah Sakit Roemani memeberikan pelayanan kesehatan yang Islami, profesional dan bermutu dengan tetap peduli terhadap kaum Dhu'afa dan anak yatim.

3. Rumah Sakit Roemani sebagai rumah sakit rujukan bagi rumah sakit Islam se Jawa Tengah.

4. Rumah Sakit Roemani sebagai mitra pengembangan keilmuan dan tenaga kesehatan, khususnya bagi institusi di lingkungan Persyarikatan Muhammadiyah.

Motto

"Rumah Sakit Keluarga Islami"

\section{Hasil Penelitian}

Tabel 4 Hasil Perhitungan Harga Pokok Dengan Activity Based Costing

\begin{tabular}{|c|c|c|c|c|c|c|c|c|}
\hline Kelas & \multicolumn{7}{|c|}{ Biaya -biaya (Rp) } & Total biaya \\
\hline & paramedis & Pem.bangunan & listrik & loundry & Makan & sanitasi & Fasilitas & Hrg pokok/hr \\
\hline Utama & 116.477 & 20.357 & $23.075,12$ & 18.238 & $62.728,40$ & 20.395 & 99.545 & $360.815,52$ \\
\hline IA & 80.471 & 1.805 & $23.075,12$ & 11219 & $46.307,28$ & 1.808 & 80.414 & $245.099,40$ \\
\hline IB & 80.748 & 6.424 & $11.537,56$ & 6903 & $57.000,49$ & 6.436 & 42.397 & $211.446,05$ \\
\hline II & 49.463 & 3.092 & $10.578,76$ & 5542 & $30.490,53$ & 3.098 & 28.364 & $130.628,29$ \\
\hline II A & 77.424 & 3.766 & $4.989,75$ & 3149 & $33.415,53$ & 3.773 & 12.895 & $139.412,28$ \\
\hline II B & 205.305 & 23.299 & $2.524,84$ & 1382 & $34.426,96$ & 23.343 & 8.505 & $298.785,80$ \\
\hline III & 55.764 & 7.154 & 102,27 & 852 & $14.536,88$ & 7.167 & 1.741 & $87.317,15$ \\
\hline
\end{tabular}




\begin{tabular}{|c|c|c|c|c|c|c|c|c|}
\hline ICU & 265.585 & 65.376 & $3.355,80$ & 5184 & - & 65.498 & 7.037 & $412.035,80$ \\
\hline PICU & 347.542 & 95.396 & $4.026,84$ & 7564 & - & 95.575 & 10.321 & $560.424,84$ \\
\hline BBRT & 230.422 & 33.066 & $4.026,84$ & 4497 & - & 33.128 & 6.136 & $311.275,84$ \\
\hline R.BAYI & 81.032 & 26.640 & $1.342,32$ & 2113 & - & 26.690 & 2.882 & $140.699,32$ \\
\hline & $\begin{array}{c}\text { 1.694.233 } \\
00\end{array}$ & $286.375,00$ & $88.635,22$ & 66.643 & $278.906,07$ & $286.911,00$ & $300.237,00$ & \\
\hline
\end{tabular}

Sumber: Data yang diolah

Tabel 4 Perbandingan Tarif Rumah Sakit Dengan Hasil Perhitungan ABC

\begin{tabular}{|c|c|c|c|c|}
\hline Kelas & $\begin{array}{c}\text { Tarif Rumah Sakit } \\
(\mathrm{Rp})\end{array}$ & $\begin{array}{c}\text { Harga Pokok ABC } \\
(\mathrm{Rp})\end{array}$ & Selisih (Rp) & $\%$ \\
\hline UTAMA & 550.000 & $360.815,52$ & $189.184,48$ & 52,43 \\
\hline I A & 450.000 & $245.099,40$ & $204.900,60$ & 83,60 \\
\hline I B & 325.000 & $211.446,05$ & $113.553,95$ & 63,15 \\
\hline II & 250.000 & $130.628,29$ & $119.371,71$ & 91,38 \\
\hline II A & 200.000 & $139.412,28$ & $60.587,72$ & 43,46 \\
\hline II B & 175.000 & $298.785,80$ & $(123.785,80)$ & $(41,43)$ \\
\hline III & 110.000 & $87.317,15$ & $22.682,85$ & 25,98 \\
\hline ICU & 450.000 & $412.035,80$ & $37.964,20$ & 9,22 \\
\hline PICU & 450.000 & $560.424,84$ & $(110.424,84)$ & $(19,71)$ \\
\hline BBRT & 250.000 & $311.275,84$ & $(61,275,84)$ & $(19,68)$ \\
\hline R.BAYI & 300.000 & $140.699,32$ & $159.300,68$ & 113,22 \\
\hline
\end{tabular}

Sumber: Data yang diolah

Berdasarkan perhitungan diatas, 43\%, 19, 71\%, dan 19,68\%. Dan tarif kelas dapat diketahui bahwa hasil perhitungan lain lebih tinggi yaitu $9 \%$ sampai $100 \%$.

tarif jasa rawat inap dengan menggunakan metode activity based costingsebagai terdapat tarif yang terlalu rendah yaitu pada

\section{Kesimpulan}

kelas IIB, PICU, dan BBRT sebesar 41,

Berdasarkan hasil perhitungan tarif jasa rawat inap pada bab sebelumnya maka dapat disimpulkan bahwa perhitungan tarif jasa rawat inap dengan menggunakan 
activity based costing, dilakukan melalui dua tahap. Tahap pertama biaya ditelusuri ke aktivitas yang menimbulkan biaya dan kemudian tahap kedua membebankan biaya ke produk. Dari perhitungan tarif jasa rawat inap dengan menggunakan activity based costing diketahui besarnya tarif sebagai berikut:

Tabel 5 Hasil perhitungan ABC

\begin{tabular}{|c|c|c|}
\hline No & Kelas & Hasil \\
\hline 1 & UTAMA & $360.815,52$ \\
\hline 2 & IA & $245.099,40$ \\
\hline 3 & IB & $211.446,05$ \\
\hline 4 & II & $130.628,29$ \\
\hline 5 & IIA & $139.412,28$ \\
\hline 6 & IIB & $298.785,80$ \\
\hline 7 & III & $87.317,15$ \\
\hline 8 & ICU & $412.035,80$ \\
\hline 9 & PICU & $560.424,84$ \\
\hline 10 & BBRT & $311.275,84$ \\
\hline 11 & R.BAYI & $140.699,32$ \\
\hline
\end{tabular}

Sumber: data yang diolah

Perbedaan tarif yang terjadi

disebabkan karena pembebanan biaya

overhead pada masing-masing produk.

Activity based costing telah mampu

mengalokasikan biaya aktivitas ke

setiap kamar secara tepat berdasarkan

konsumsi masing-masing aktivitas.

Saran

Rumah Sakit Roemani

Muhammadiyah sebaiknya mulai

mempertimbangkan tarif rawat inap

dengan menggunakan activity based

costing karena dengan activity based costing akan diperoleh informasi biaya rawat inap yang lebih akurat. Karena, perhitungan Activity Based Costing berorientasi pada penggunaan biaya real dan perhitungan sesuai aktivitasaktivitas yang dikonsumsi oleh setiap kelas kamar rawat inap .

\section{DAFTAR PUSTAKA}

Garrison, Ray H. Eric W Norren, 2000. "Management Accounting."

DiterjemahkanOleh

A. TotokBudisantosoDenganJu 
dulAkuntansiManajerial.

Buku 1. Jakarta:

SalembaEmpat.

Hansen, D. R., Maryanne M. Mowen, 2006."AkuntansiManajemen

." Edsisi 7. Jakarta:

SalembaEmpat. 